\title{
THE SCENARIO-BASED APPROACH TO TRADE IN OPTION CONTRACTS
}

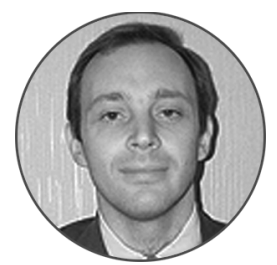

\author{
Mikhail E. SEMENOV \\ National Research Tomsk Polytechnic University (TPU), Tomsk, Russian Federation \\ sme@tpu.ru \\ Corresponding author
}

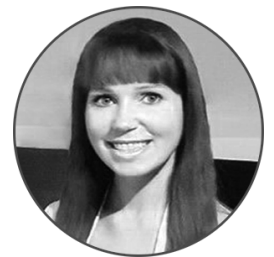

\section{Margarita E. FAT'YANOVA}

National Research Tomsk Polytechnic University (TPU), Tomsk, Russian Federation mef1@tpu.ru

\section{Article history:}

Received 10 September 2018

Received in revised form

12 October 2018

Accepted 3 November 2018

Translated 15 March 2019

Available online 29 March 2019

JEL classification: C58, C61, G11, G17, G24

Keywords: scenario-based approach, scenario tree, geometric motion, call option

\begin{abstract}
Subject Nowadays, traditional methods may hardly forecast how prices for assets will go. The scenario-based approach becomes more widely spread in various sciences, including financial mathematics. The key idea of the scenario-based approach is a scenario tree representing the hierarchical structure of data, outlining how things may unfold, and evaluating the probability. This approach helps model various scenarios of the future situation, thus allowing to make appropriate decisions.

Objectives The research produces a one-period scenario tree showing how the price for the asset may develop. We also analyze the sensitivity of the parameter influencing the number of descendants of vertices.

Methods The research is based on the economic-mathematic model of the geometric (Brownian) motion, which is expressed through the stochastic differential equation. The model and sensitivity analysis are implemented in MATLAB. We also applied methods of comparative and static analysis, graphic interpretation.

Results We constructed a one-period scenario tree for a change in the options price. Having analyzed the sensitivity of the descendant vertex parameter, we determined the optimal range of option strike price intervals.

Conclusions and Relevance We chose the geometric motion model as the basis for the scenario-based approach since it helps construct the one-period scenario tree. This approach allows to evaluate the scenario probability. However, its weakness is that it generates the unoptimal number of descendant vertex of a tree. Furthermore, the market situation requires to test the asset for liquidity through various metrics. For example, the number of deals and trading volume.
\end{abstract}

The editor-in-charge of this article was Irina M. Vechkanova

Authorized translation by Irina M. Vechkanova

\section{Introduction}

Due to uncertainty in the financial market and distant investment horizon, traditional forecasting methods

${ }^{\dagger}$ For the source article, please refer to: Семёнов M.E., Фатьянова М.Э. Применение сценарного подхода для опционной торговли // Финансовая аналитика: проблемы и решения. 2019. T. 12. № 1. C. 72-89. URL: https://doi.org/10.24891/fa.12.1.72 often cause substantial errors and inaccuracy. This directly results from human interference into the interpretation of initial data. The scenario-based approach is very efficient since it implies the examination of key scenarios of future developments. The scenario-based approach came into practice in various areas, i.e. strategic planning and risk analysis 
[1-3], management and portfolio investment, financial mathematics $[4,5]$.

This research continues the previous studies [6, 7] which constructed complex portfolios of stock options $[8,9]$. The key idea behind the studies was to address issues of linear programming and measure the optimal number of assets. However, those studies failed to consider possible changes in prices for underlying assets over time. The scenario-based approach takes this fact into account indeed. The research focuses on this aspect.

\section{The Development of the General Methodology for the Scenario-Based Approach}

The scenario-approach methodology originated in the 1960s. There appeared the first definitions of scenario and methodological framework for analysis. The pioneering studies were devoted to forecast of oil prices $[10,11]$, political and social processes [12]. Other proceedings delve into the essentials of the scenariobased approach in strategic management and decision making, psychological aspects of scenario development.

The studies point out several fundamental purposes of the scenario analysis:

1) foreseeing possible losses in the future in line with various factors ${ }^{1}$;

2) identifying the appropriate and suitable strategic decision in a respective case [13];

3) revising the current decisions and knowingly adjust them for the future situation.

Fig. 1 summarized two approaches to unfolding the concept scenario as the literature analysis shows. In the first column, the concept scenario is viewed from perspectives of predicting probabilities of the future strategies, whilst in the second column the necessity of methods is emphasized.

The term scenario is often used incorrectly, meaning forecast and vision. However, as the definitions in Fig. 1 show, scenario is not forecast, i.e. the description of the relatively predictable outcome of the current events. In the mean time, scenario is not a vision, i.e. a view of the desirable future. Scenario shall be a possibility to find a

\footnotetext{
${ }^{1}$ Neilson R., Wagner C. Strategic Scenario Planning at CA International. Knowledge Management Review, 2000, no. 12, pp. 4-21.
}

reasonable, elaborate and, more often than note, estimated answer to the what-if question.

Fig. 2 illustrates a fundamental comparison of three concepts - vision, forecast and scenario [14]. We should note that what differentiates scenario from the other two notions is an opportunity to manage risks, whilst vision and forecast imply the tendency of concealing them.

According to the main classification of scenarios, there are two types of them [14]:

1) prospective scenarios reflect a process as if development trends remain unchanged;

2) normative scenarios outline alternative ways of attaining desired goals and forecast how the goals can be achieved.

Let us understand the scenario tree as a variety of possible outcomes in the future and assessment of the probability of each interim and resulting scenarios.

Making the scenario tree, we necessarily determine the optimal number of relevant sets. M. Porter suggests taking a set of three scenarios - the best-case, worstcase and base (as the most probable) scenarios. According to the research referred to herein [15], the above classification is far from being perfect since the base scenario may conflict with the other two. To eliminate the controversy, the author suggest setting two or three macroscenarios, which would subsequently engender their individuals scenarios, thus ensuring the logic consistency of the tree. The studies exemplify how scenario trees are made [16-18].

Another study [19] describes a methodological approach to making a scenario tree for a portfolio of option contracts, considering the probabilistic weight of a path from one vertex to the other one. However, the model has a narrow point of measuring the value $\sigma$ determining the number of tree vertices at each step (the interval width of the strike price of options). In the study, researchers fail to verify the liquidity of strike prices in the real market. We are going to assess the model in more detail, conduct a sensitivity analysis of the value and check the liquidity of the resultant strike prices. Whereas this research continues the studies of other authors $[6,7]$, we choose the price for options in RTS futures contracts as the underlying asset.

Please cite this article as: Semenov M.E., Fat'yanova M.E. The Scenario-Based Approach to Trade in Option Contracts. Digest Finance, 2019, vol. 24, iss. 1, pp. 96-108. 


\section{The Mathematical Model for a Scenario Tree}

The linear Bachelier model is the simplest model of the underlying asset price [20]:

$$
S_{t}=S_{0}+r \cdot t+\sigma \cdot W_{t} \text {, }
$$

where $S_{t}$ is the asset price, $S_{0}$ is the initial asset price, $r$ is a risk-free interest rate, $\sigma$ is volatility, $W_{t}$ is the Wiener process.

It was L. Bachelier who performed the first empirical research verifying the random walk hypothesis. Under the random walk hypothesis, the financial result of investment in assets has no serial correlation, and the probability of such random walks tend to be invariant. The Bachelier model (1) has a serious drawbacks as it may produce the negative value of $S_{t}$.

The Brownian motion (geometric, economic) [21] is believed to me more realistic, where $S_{t}$ is expressed as a stochastic differential equation:

$$
d S_{t}=r \cdot S_{t} \cdot d t+\sigma \cdot S_{t} \cdot d W_{t}
$$

or

$$
\frac{d S_{t}}{S_{t}}=r \cdot d t+\sigma \cdot d W_{t} .
$$

Applying the Itô's lemma ${ }^{2}$, we find the differential of $\ln S_{t}$ for the expression (2):

$$
d \ln S_{t}=\left(r-\frac{\sigma^{2}}{2}\right) d t+\sigma \cdot d W_{t} .
$$

Having performed the integration of the expression (3) within the interval $[0 ; t]$, we arrived at the solution of the equation (2) as:

$$
S_{t}=S_{0} \cdot \exp \left\{H_{t}\right\}
$$

where

$$
H_{t}=\left(r-\frac{\sigma^{2}}{2}\right) \cdot t+\sigma \cdot W_{t}=\ln \left(S_{t} / S_{0}\right) ;
$$

$H=\left(H_{t}\right)_{t \geq 0}$ is the process of the Brownian motion ${ }^{3}$ with the volatility $\sigma^{2}$ and local drift

$$
\left(r-\frac{\sigma^{2}}{2}\right)
$$

\footnotetext{
${ }^{2}$ Piskunov N.S. Differentsial'noe I integral'noe ischisleniya [Differential and integral computations]. Moscow, Fizmatlit Publ., 1996, 416 p.

${ }^{3}$ Volkov I.K., Zuev S.M., Tsvetkova G.M. Sluchainye protsessy [Random processes]. Moscow, Bauman MSTU Publ., 1999, 448 p.
}

The latter is a characteristic of the average pace at which the process $H=\left(H_{t}\right)_{t \geq 0}$ changes, with the random value being

$$
\begin{aligned}
& H_{t} \sim N\left(\left(r-\sigma^{2}\right), \sigma^{2} \cdot t\right), \quad \text { and } \\
& S_{t} \sim \log N \exp \{r \cdot t\} \cdot S_{0}, \\
& \exp \{2 \cdot r \cdot t\} \cdot S_{0}^{2} \cdot \exp \left\{\sigma^{2} \cdot t\right\}-1 .
\end{aligned}
$$

The Wiener process $W_{t}$ shall mean a mathematical model of the ordinary Brownian motion, as set by $\mathrm{N}$. Wiener in 1923 [22] relying upon the proceedings by L. Bachelier [20]. It is noteworthy that $W_{t}$ constitutes the random walk model with the uninterrupted trajectory and time and independent Gaussian (normally distributed) increments.

We adhere to the following rules when constructing the scenario tree.

3. At step $\tau=\overline{1, t}$, the first (last) descendant vertex corresponds to the highest (lowest) possible price for the underlying asset.

4. The underlying asset price in neighboring descendant vertices shall differ by the value $\Delta>0$, which is equal to a price increment of the underlying asset.

5. Logarithms of the ratio of the underlying asset prices in the first $S_{(n, \tau)}^{1}$ and the last $S_{(n, \tau)}^{N(n, \tau)}$ descendant vertices to the underlying asset price in the respective ancestor vertex $S_{(n, \tau)}$ shall cover the entire interval $\left[a_{\tau} ; b_{\tau}\right]$ :

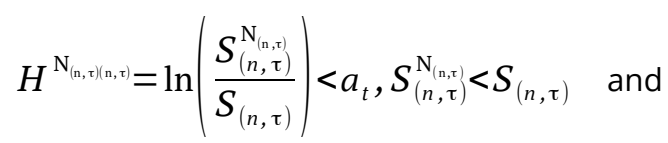

$H_{(n, \tau)}^{1}=\ln \left(\frac{S_{(n, \tau)}^{1}}{S_{(n, \tau)}}\right)>b_{\tau}, S_{(n, \tau)}^{1}>S_{(n, \tau)}$,

where $N_{(n, \tau)}$ is the number of descendants of the ancestor vertex $(n, \tau)$.

6. The lower and upper edges of the interval $\left[a_{\tau} ; b_{\tau}\right]$ are determined through the following formulas:

$$
\begin{aligned}
& a_{\tau}=\left(r-\frac{\sigma^{2}}{2}\right) \cdot\left(\frac{t_{\tau}}{t d}\right)-\delta \cdot \sigma \cdot \sqrt{\frac{t_{\tau}}{t d},} \\
& b_{\tau}=\left(r-\frac{\sigma^{2}}{2}\right) \cdot\left(\frac{t_{\tau}}{t d}\right)+\delta \cdot \sigma \cdot \sqrt{\frac{t_{\tau}}{r d}},
\end{aligned}
$$

where $t_{\tau}$ is the number of days prior to the following step $(\tau+1) ; t d$ is the number of trading days a 
year; $\delta$ coefficient is measured with the desired probability $\operatorname{Pr}$ that the underlying asset price will fall within the interval $\left[a_{\tau} ; b_{\tau}\right]$.

Let us assess the conditional probability $p_{(n, \tau)}^{i}$ that the descendant vertex $i$ will proceed from the ancestor vertex $(n, \tau)$ in accordance with the rule:

$$
p_{(n, \tau)}^{i}= \begin{cases}1-N\left(x_{-}^{i}\right), & i=1 \\ N\left(x_{+}^{i}\right)-N\left(x_{-}^{i}\right), & i=\overline{2,\left(N_{(n, \tau)}-1\right)}, \\ N\left(x_{+}^{i}\right), & i=N_{(n, \tau)}\end{cases}
$$

where

$$
N\left(x_{+-}^{i}\right) \sim\left(\left(r-\frac{\sigma^{2}}{2}\right) \cdot \frac{t_{\tau}}{t d}, \sigma \cdot \sqrt{\frac{t_{\tau}}{t d}}\right) .
$$

The value of $x_{+-}^{i}$ is measured with the formula below

$$
x_{+-}^{i}=\ln \left(\frac{S_{(n, \tau)}^{i} \pm \Delta / 2}{S_{(n, \tau)}}\right) \text {. }
$$

The number of descendants of the ancestor vertex is expressed as

$N_{(n, \tau)}=N_{(n, \tau)}^{u p}+N_{(n, \tau)}^{\text {down }}+1$.

$N_{(n, \tau)}^{u p}$ denotes the number of descendants of the ancestor vertex $(n, \tau)$ for which the inequation is true $S_{(n, \tau)}^{i}>S_{(n, \tau)}, N_{(n, \tau)}^{\text {down }}$ is the number of descendants of the ancestor vertex $(n, \tau)$ for which the inequation $S_{(n, \tau)}^{i}<S_{(n, \tau)}, i=\overline{1, N_{(n, \tau)}}$ is true.

The probability of the scenario is determined as follows.

$$
P_{v}=\prod_{t=2}^{T} p_{v}^{t}
$$

where $p_{v}^{t}$ is the conditional probability that the ancestor vertex will generate a descendant at the step $t$ in case of the scenario $v, t=\overline{2, T}, u=\overline{1, N}$.

For controlling the measured probabilities of the scenarios $P_{v}$ and probabilities of descendants proceeding from the vertex $(n, \tau)$, the following normalization conditions should be in place respectively:

$$
\sum_{v=1}^{N} P_{v}=1 \text { and } \sum_{i=1}^{N_{(n, \tau)}} p_{(n, \tau)}^{i}=1 .
$$

\section{Numerical Performance}

Continuing the research indicated herein [6, 7], we focus on the following task. We need to make a financial portfolio of call options contracts for short-term investment of monetary funds. In this case, at the first step the scenario tree should be constructed to show how the price for the underlying asset changes. The second step is about the optimization $[6,7]$.

In this article, we give a numerical example of the scenario tree construction. The futures contract for RTS index is the underlying assets for purposes of this research. Whereas we deal with short-term investment, the two-step procedure will be performed, taking $T=$ 2 and $t_{\tau}=22$ days. The risk-free interest rate $r$ is accepted as the lowest short-term rate on RUBdenominated direct REPO transactions through auctions with the Central Bank of Russia: $r=7.25$ percent. The volatility is chosen from the volatility curve graph: $\sigma=24.51$ percent. The rest of the parameters are presented in Table 1.

As per the formula (2), the value of options contracts depends on the price of the underlying asset, risk-free interest rate, volatility and period before vesting. Therefore, the risk-free interest rate and volatility are permanent values, while some random process $\xi_{t}$ describes only changes in the price for the underlying asset.

As a result of the modeling process, we constructed the scenario tree. Fig. 3 depicts its concise form. Table 2 indicates all resultant probabilities of the scenarios.

The resultant tree reflects the development of a random process $\xi_{t}$ for two steps $(T=2)$. The state of the process at each step is presented as numbers above the tree peaks. At the step $\tau=1$, the root vertex $(1,1)$ has the value of $S_{(1,1)}=107,500$ points. At the step $\tau=2$, the ancestor vertex $\mathrm{N}_{(1,1)}$ has 16 descendants. Then $\xi_{t}$ can turn into any value $S_{(1,1)}^{i}$ within the interval $[90,000 ; 127,500]$ with an increment of the underlying asset price equal to $\Delta=2,500$ points.

Branches of the scenario tree show the probability of transit from an ancestor vertex to a descendant vertex. For example, at the step $\tau=2$, the conditional probability of the descendant vertex $i$ proceeding from the ancestor vertex $(1,1)$ equals 0.0139 . In the mean time, the conditional probability of the fifteenth descendant vertex proceeding from the ancestor vertex $(1,1)$ equals $p_{(1,1)}^{15}$ is 0.0151 . 
As per the formula (10), the probability of the scenarios will be as follows: $P_{1}=0.0139, P_{15}=0.0151$. The normalization conditions (11) are met for the values given in Table 2.

\section{The Effect of $\delta$ on the Interval Width of Strike Prices}

The liquidity of the derivatives market influences and respectively limits the use of the resultant scenario tree. It may be that the probability of the resultant scenario is more than zero, but the scenario is a priori unfeasible and impracticable. The liquidity of options contracts are measured with the open interest (Fig. 4) and trading volume (Fig. 5).

Open interest represents the total number of contracts that are not closed or delivered, continuing to exist as of the current date and being due in the future definite period. The assumption is that if the buyer and seller agreed on a contract, the open interest value increased by two contracts (one from each party). Fig. 4 presents a graph reflecting the number of open positions for call options on RTS index futures contracts per various strike prices as of the scenario tree date (corresponding with Table 1).

Trading volume shows the number of contracts concluded within a certain period of time (day, week). If trading volume with respect to some strike price under the options contract increases, it signifies the arising interest of the market actors and raises its liquidity respectively. Fig. 5 displays the graph of trading volume for the call options contract on the RTS index futures per different strike prices as of the scenario tree date (corresponding to Table 1). Fig. 4 and Fig. 5 shows that the options contract with the strike price of 107,500 points corresponds with the largest number of open positions and trading volume. It is due to the fact that the value of $S_{(1,1)}$, i.e. 107,500 points, is the central strike price [23].

Let us consider the economic interpretation of coefficients in the formula (4). The $r$-coefficient serves as the value of the potential asset growth. The expression $(r-0.5)$ is average of the instant pace of change in a random process $H=\left(H_{t}\right)_{t \geq 0}$. The coefficient $\sigma^{2}$ determines the diffusion of the instant pace of change in the financial result (volatility). The base rule for selecting the value $\delta$ is called the three sigma rule.
Let us substitute the mathematical expectation of a random value with the normal distribution, taking it as $m=E\left(H_{t}\right)$. Then as seen in the distribution curve, 99.7 percent of all possible outcomes with respect to the underlying asset price as of the vesting date of the options contract will lie within the range of three standard deviations ( $\delta=3$ ), and 95.4 percent will fall within the range of two standard deviations ${ }^{4}$ :

$\operatorname{Pr}(-2 \sigma<m<2 \sigma)=0.954 ; \delta=2$;

$\operatorname{Pr}(-2.326 \sigma<m<2,326 \sigma)=0.98 ; \delta=2.326$;

$\operatorname{Pr}(-3 \sigma<m<3 \sigma)=0.997 ; \delta=3$.

Assigning different values to $\delta$, we assess the extent to which this parameter influences the interval width $\left[a_{\tau} ; b_{\tau}\right]$. The values of the remaining parameters of the model correspond with the previous ones (Table 1). Fig. 6 presents the graphs showing the distribution of the modelled probabilities for various values of $\delta$. , The parameter $\delta$ evidently influences the interval width $\left[a_{\tau} ; b_{\tau}\right]$ and the number of descendants $N_{(n, \tau)}$ proceeding from the ancestor vertex.

The probability distribution graph is not symmetric (Fig. 6) against the central strike price of 107,500 points. It also demonstrates the right-hand drift of curves. This is evidence of a strong probability of growth in the underlying asset price, rather than a drop. This assumption is empirically corroborated (Table 3).

As per Table 3, the scenario tree has more rising descendants $N_{(n, \tau)}^{u p}$ than falling ones $N_{(n, \tau)}^{\text {down }}$ (we mean an increase and decrease in the price for the underlying asset). Hence an increase in the parameter $\delta$ results in a stronger probability $\mathrm{Pr}$ and the greater number of descendants from the ancestor vertex. The numerical outcome of modeling is given in Table 4 and Table 5.

As per Tables 2-5, the price for the underlying asset as of the options vesting date will lie within the range of strike prices:

[92,500; 125,000] with a 95.4\% probability $\operatorname{Pr;}$

$[90,000 ; 127,500]$ with a 98\% probability $\operatorname{Pr}$;

[85,000; 135,000] with a 99,7\% probability Pr.

Hence, as the parameter $\delta$ increases, the range of strike prices widens. However, such a range is not

\footnotetext{
${ }^{4}$ Silant'ev S.A. Logika optsionnoi torgovli [Logic of trade in options contracts]. Moscow, SmartBook, I-treid Publ., 2008, 344 p.
} 
always the best width of the strike price interval in terms of their liquidity.

As the input data show (Table 1), investment is made for a short-term period. According to the research indicated herein [24], it is unreasonable to distant values of strike prices with respect to the present-day price for the underlying asset in the case of short-term investment. Furthermore, in the case of short-term investment, a range exceeding 40 percent is not advisable. Thus, the scenario tree should be constructed for an options contract, strike prices of which range from 60 percent to 140 percent of the current price for the underlying asset.

The resultant intervals of strike prices for the three cases (Table 3 ) have a range which does not exceed 40 percent. To precise the interval, it is necessary to refer to key metrics of options liquidity, i.e. open interest and trading volume. The graphs in Fig. 4 and 5 show the very low liquidity of options contracts with strike prices below 100,000 points. Therefore, it would be more reasonable to set the left-hand edge of the interval at 100.000 points. The right-hand edge should be set at 127,500 points $(P r=98 \%)$ or $135,000(P r=99.7 \%)$ indeed. Both cases are tolerable and acceptable.

\section{Conclusion}

In this research, we provided a profound description of the methodological approach to constructing scenario trees for options contract, considering the probability of transition from an ancestor node to a descendant vertex. The geometric (Brownian) motion model underlies our numerical modeling of trends in the price for the underlying asset. Using the model, we designed the one-period scenario tree (Fig. 3) and measured strike prices of the options contract and their respective probabilities. The assessment of the parameter $\delta$ appeared to be a bottle neck in the use of the model since it determines a range of strike prices for the options contract. Fig. 6 displays the log-normal distribution of probabilities in line with the three values of the parameter $\delta$. The graph is seen to have a righthand drift, signifying that there is a strong probability that the price for the underlying asset will be rising than falling. The fact is corroborated numerically in Table 3. The number of rising descendant vertices of a corresponding ancestor node $N_{(n, \tau)}^{u p}$ always exceeds the number of falling descendant vertices $N_{(n, \tau)}^{\text {down }}$.

The three sigma rule ensures a strong probability that strike prices for the options contract will widely range. However, the rule still has a serious drawback. It overlooks the liquidity of the options contract with a corresponding strike price in the real market. That is the reason why various indicators should be employed since they make up a correct view of the liquidity. In this research, we analyzed two key indicators, i.e. the number of open transactions (open interest) and trading volume. As the analysis shows, strike prices below 100,000 points of the underlying asset proved to be non-marketable in case of short-term investment. Therefore, such strike prices should not be used for constructing scenario trees for subsequent steps. 


\section{Table 1}

\section{Scenario tree parameters}

\begin{tabular}{ll}
\hline Metrics & Value \\
\hline Portfolio composition & Options on RTS index futures contract \\
\hline Current price for the options contract $S_{(1,1)}$ & 107,500 points \\
\hline Increment of the underlying asset price $\Delta$ & 2,500 points \\
\hline Number of steps $T$ & 2 \\
\hline Term of investment $t \tau$ & 22 \\
\hline Risk-free interest rate $r$ & $7.25 \%$ \\
\hline Volatility $\sigma$ & $24.51 \%$ \\
\hline Coefficient $\delta$ & 2.326 \\
\hline Number of trading days a year $t d$ & 247 \\
\hline
\end{tabular}

Source:Authoring

\section{Table 2}

The probability of scenario $\boldsymbol{P}_{V}$ to arrive at the descendant vertex

\begin{tabular}{ll}
\hline $\boldsymbol{S}_{(\mathbf{1}, \mathbf{1})}$ & $\boldsymbol{P}_{\boldsymbol{V}}$ \\
\hline 90,000 & 0.0095 \\
\hline 92,500 & 0.0151 \\
\hline 95,000 & 0.0304 \\
\hline 97,500 & 0.0527 \\
\hline 100,000 & 0.0793 \\
\hline 102,500 & 0.105 \\
\hline 105,000 & 0.1231 \\
\hline 107,500 & 0.1291 \\
\hline 110,000 & 0.1218 \\
\hline 112,500 & 0.1043 \\
\hline 115,000 & 0.0814 \\
\hline 117,500 & 0.0584 \\
\hline 120,000 & 0.0386 \\
\hline 122,500 & 0.0237 \\
\hline 125,000 & 0.0135 \\
\hline 127,500 & 0.0139 \\
\hline
\end{tabular}

Source:Authoring

\section{Table 3}

The number of descendants of the ancestor vertex in line with three values of $\delta$

\begin{tabular}{llll}
\hline Metrics & Value of $\delta$ & & \\
\hline$P r, \%$ & 95.4 & 98 & 99.7 \\
\hline$N_{(n, \tau)}^{u p}$ & 7 & 8 & 11 \\
\hline$N_{(n, \tau)}^{\text {down }}$ & 6 & 7 & 9 \\
\hline$N_{(n, \tau)}$ & 14 & 16 & 21 \\
\hline Interval of strike prices & {$[92,500 ; 125,000]$} & {$[90,000 ; 127,500]$} & {$[85,000 ; 135,000]$} \\
\hline
\end{tabular}

Source:Authoring 


\section{Table 4}

The modeling outcome for $\delta=2$

\begin{tabular}{ll}
\hline $\boldsymbol{S}_{(\mathbf{1}, \mathbf{1})}$ & $\boldsymbol{P}_{\boldsymbol{V}}$ \\
\hline 92,500 & 0.0247 \\
\hline 95,000 & 0.0304 \\
\hline 97,500 & 0.0527 \\
\hline 100,000 & 0.0793 \\
\hline 102,500 & 0.105 \\
\hline 105,000 & 0.1231 \\
\hline 107,500 & 0.1291 \\
\hline 110,000 & 0.1218 \\
\hline 112,500 & 0.1043 \\
\hline 115,000 & 0.0814 \\
\hline 117,500 & 0.0584 \\
\hline 120,000 & 0.0386 \\
\hline 122,500 & 0.0237 \\
\hline 125,000 & 0.0275 \\
\hline
\end{tabular}

Source:Authoring

\section{Table 5}

The modeling outcome for $\delta=3$

\begin{tabular}{ll}
\hline $\boldsymbol{S}_{(\mathbf{1}, \mathbf{1})}$ & $\boldsymbol{P}_{\boldsymbol{V}}$ \\
\hline 85,000 & 0.0009 \\
\hline 87,500 & 0.0023 \\
\hline 90,000 & 0.0064 \\
\hline 92,500 & 0.0151 \\
\hline 95,000 & 0.0304 \\
\hline 97,500 & 0.0527 \\
\hline 100,000 & 0.0793 \\
\hline 102,500 & 0.105 \\
\hline 105,000 & 0.1231 \\
\hline 107,500 & 0.1291 \\
\hline 110,000 & 0.1218 \\
\hline 112,500 & 0.1043 \\
\hline 115,000 & 0.0814 \\
\hline 117,500 & 0.0584 \\
\hline 120,000 & 0.0386 \\
\hline 122,500 & 0.0237 \\
\hline 125,000 & 0.0135 \\
\hline 127,500 & 0.0072 \\
\hline 130,000 & 0.0036 \\
\hline 132,500 & 0.0017 \\
\hline 135,000 & 0.0013 \\
\hline
\end{tabular}

Source:Authoring

Please cite this article as: Semenov M.E., Fat'yanova M.E. The Scenario-Based Approach to Trade in Option Contracts. Digest Finance, 2019, vol. 24, iss. 1, pp. 96-108. 


\section{Figure 1}

The general view of approaches to revealing the Scenario definition

\begin{tabular}{|l|l|}
\hline Approach 1 & Approach 2 \\
\hline $\begin{array}{l}\text { 1. Internal perception of the future. It is not } \\
\text { forecast but rather some version of the possible } \\
\text { future consequence (1985, M. Porter) }\end{array}$ & $\begin{array}{l}\text { 1. The reasonable method to search for various } \\
\text { strategies of the future (1995, P. Shoemaker) }\end{array}$ \\
$\begin{array}{l}\text { 2. An array of diverse but rather probable events } \\
\text { in the future (1996, Vender Heijden) }\end{array}$ & $\begin{array}{l}\text { 2. A tool to streamline alternative scenarios } \\
\text { of the future }\end{array}$ \\
$\begin{array}{l}\text { 3. Sequence of events, which may possibly take } \\
\text { place in the future (1998, M. Jarke) } \\
\begin{array}{l}\text { 4. A set of strategies with the different outcome } \\
\text { in the future (2000, Roubelat) }\end{array}\end{array}$ \\
\hline
\end{tabular}

Source:Authoring

\section{Figure 2}

Comparison of three concepts, Vision, Forecast, and Scenario

\begin{tabular}{|c|c|c|}
\hline Vision & Forecast & Scenario \\
\hline $\begin{array}{l}\text { The desired outcome } \\
\text { in the future }\end{array}$ & $\begin{array}{l}\text { The probable outcome } \\
\text { in the future }\end{array}$ & $\begin{array}{l}\text { Possible but the most probable } \\
\text { outcome in the future }\end{array}$ \\
\hline Urging to decide & Helping to date and decide & $\begin{array}{l}\text { Serving to get a sound understanding } \\
\text { a choice to be made }\end{array}$ \\
\hline \multicolumn{3}{|l|}{ Key Characteristics } \\
\hline Based on personal values & $\begin{array}{l}\text { Based on ties arranged } \\
\text { in a specific fashion }\end{array}$ & Based on uncertainty \\
\hline \multicolumn{2}{|l|}{ Risks are concealed } & Risks are showed \\
\hline $\begin{array}{l}\text { As a rule, focusing } \\
\text { on the quality }\end{array}$ & $\begin{array}{l}\text { Mainly focusing } \\
\text { on the quantity }\end{array}$ & Focusing on both quality and quantity \\
\hline \multicolumn{3}{|l|}{ Use } \\
\hline Relatively frequent & & Seldom \\
\hline \multicolumn{3}{|l|}{ Efficiency } \\
\hline $\begin{array}{l}\text { A launching mechanism } \\
\text { for the future deliberate } \\
\text { transformations }\end{array}$ & $\begin{array}{l}\text { For the short-term interval } \\
\text { Possible but the mos } \\
\text { probable outcome } \\
\text { in the futureof time } \\
\text { (low uncertainty) }\end{array}$ & $\begin{array}{l}\text { For the mid-term and long-term } \\
\text { interval of time (high or medium } \\
\text { uncertainty) }\end{array}$ \\
\hline
\end{tabular}

Source:Authoring

Please cite this article as: Semenov M.E., Fat'yanova M.E. The Scenario-Based Approach to Trade in Option Contracts. Digest Finance, 2019, 


\section{Figure 3}

The scenario tree for numerical implementation

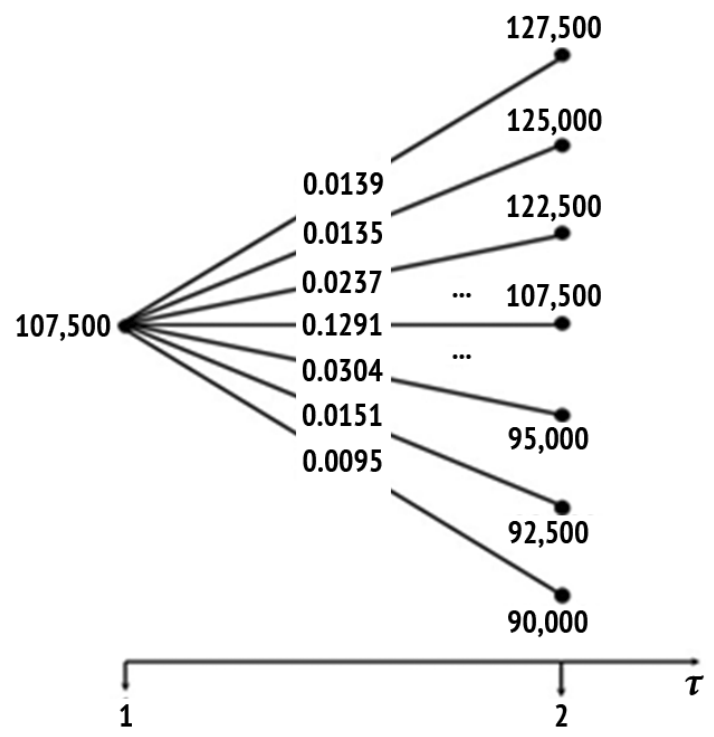

Source:Authoring

\section{Figure 4}

The declared interest in an option on the RTSI futures contract

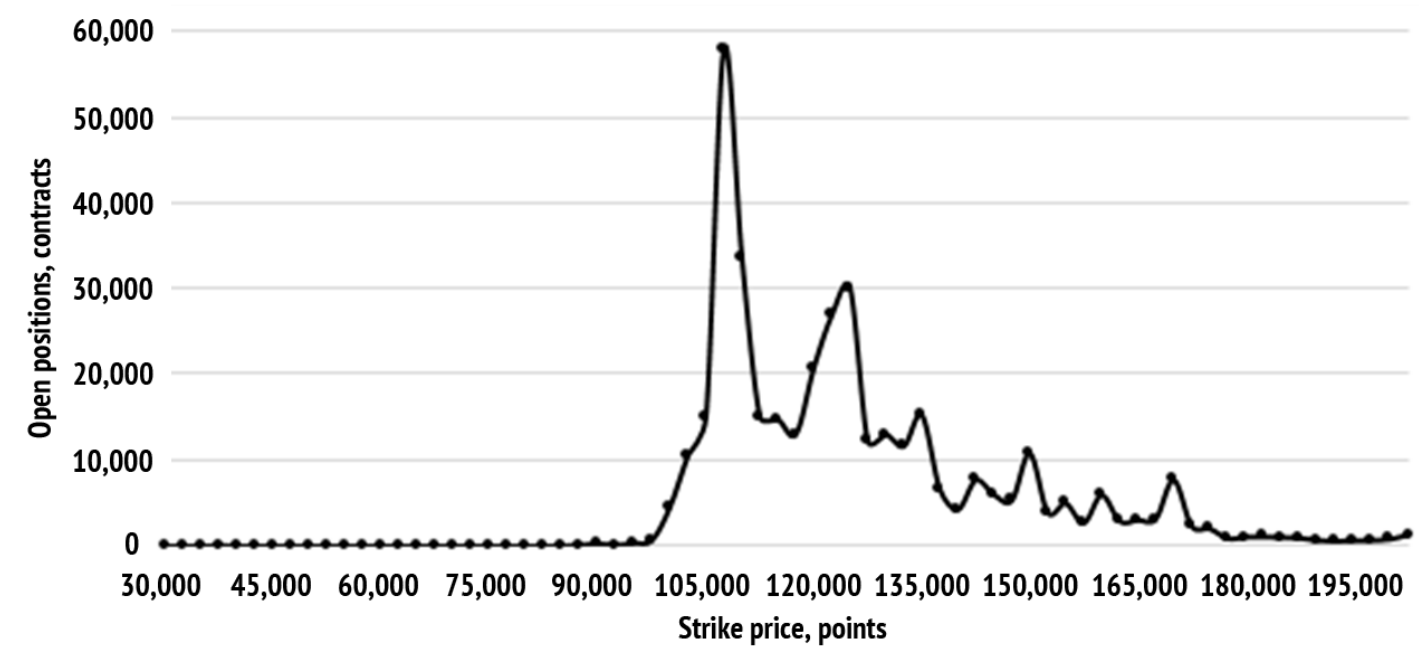

Source:Authoring

Please cite this article as: Semenov M.E., Fat'yanova M.E. The Scenario-Based Approach to Trade in Option Contracts. Digest Finance, 2019, vol. 24, iss. 1, pp. 96-108. 
Figure 5

Trading volume under the option on the RTSI futures contract

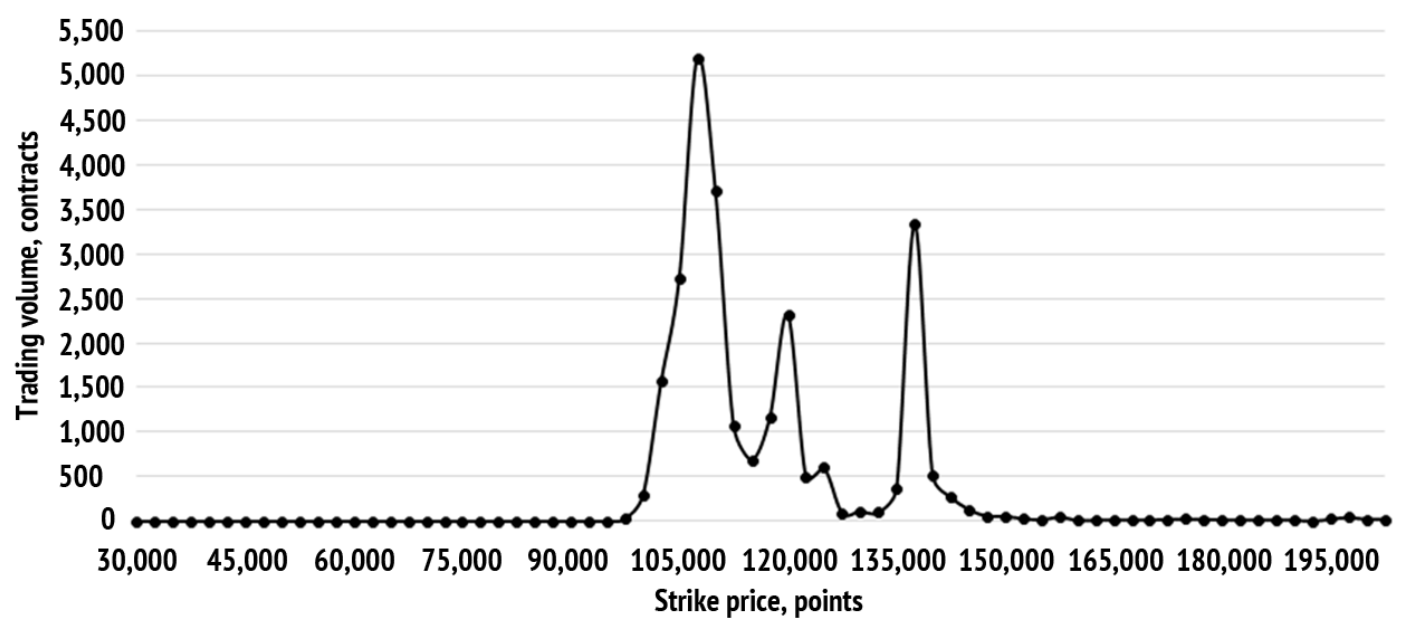

Source:Authoring

\section{Figure 6}

The distribution of probabilities in case of different values of $\delta$

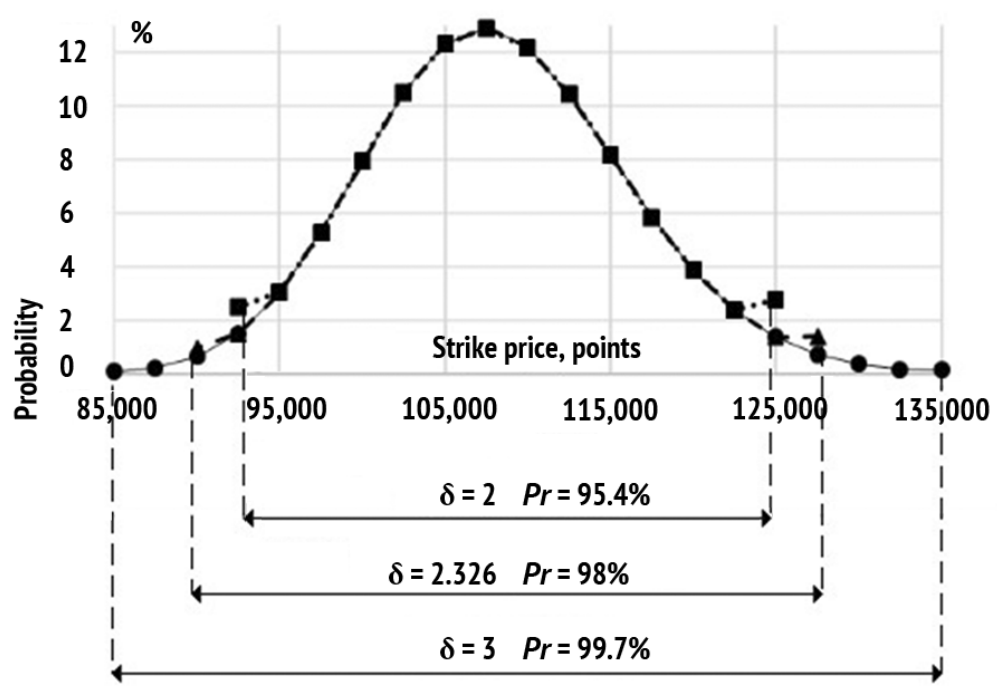

Source:Authoring 


\section{References}

1. Var'yash I.Yu., Nikonov I.V. [Macroeconomic forecasting: The composition of probabilities versus the conflict of scenarios]. Finansovaya analitika: problemy i resheniya = Financial Analytics: Science and Experience, 2015, vol. 8, iss. 43, pp. 13-21. URL: https://cyberleninka.ru/article/v/makroekonomicheskoe-prognozirovanie-kompozitsiyaveroyatnostey-protiv-konflikta-stsenariev (In Russ.)

2. Zubarev A.A., Sbitnev A.E. [Formation of the method of risk analysis of road-building projects based on the scenario approach]. Finansy $i$ kredit = Finance and Credit, 2011, vol. 17, iss. 48, pp. 37-41.

URL: https://cyberleninka.ru/article/v/formirovanie-metodiki-analiza-riskov-dorozhno-stroitelnyh-proektov-naosnove-stsenarnogo-podhoda (In Russ.)

3. Shapiro V.Ya., Shapiro N.A. [Risk assessment of portfolio investments using Markov chains]. Finansy $i$ kredit $=$ Finance and Credit, 2007, vol. 13, iss. 33, pp. 33-38. URL: https://cyberleninka.ru/article/v/otsenka-riskaportfelnyh-investitsiy-s-ispolzovaniem-tsepey-markova (In Russ.)

4. Beketov N.V., Fedorov V.G. [Traditional methods for assessing the effectiveness of investment projects]. Finansovaya analitika: problemy i resheniya = Financial Analytics: Science and Experience, 2008, vol. 1, iss. 3, pp. 75-83. URL: https://cyberleninka.ru/article/v/traditsionnye-metody-otsenki-effektivnosti-investitsionnyhproektov (In Russ.)

5. Shapiro V.Ya., Shapiro N.A. [Modeling of portfolio investments in conditions of negative scenarios of the development of the stock market]. Finansy i kredit = Finance and Credit, 2008, vol. 14, iss. 15, pp. 39-51. (In Russ.)

6. Mitsel' A.A., Semenov M.E., Fat'yanova M.E. [A combinatorial model of option portfolio]. Finansovaya analitika: problemy i resheniya = Financial Analytics: Science and Experience, 2016, vol. 9, iss. 25, pp. 2-13. URL: https://cyberleninka.ru/article/v/kombinatornaya-model-optsionnogo-portfelya (In Russ.)

7. Fatyanova M., Semenov M.E. Model for Constructing an Options Portfolio with a Certain Payo Function. CEUR Workshop Proceedings: Online Proceedings for Scientific Conferences and Workshops, MM-ITNT 2017, International Conference Information Technology and Nanotechnology. Samara, Samara State University Publ., 2017, vol. 1904, pp. 254-262.

8. Yashin S.N., Trifonov Yu.V., Koshelev E.V. [Using a real put option to manage risks of cluster's innovation strategy]. Finansy i kredit = Finance and Credit, 2017, vol. 23, iss. 26, pp. 1518-1532. (In Russ.) URL: https://doi.org/10.24891/fc.23.26.1518

9. Gracheva M.V., Petreneva E.A. [Real options as project risk management tools]. Finansovaya analitika: problemy i resheniya = Financial Analytics: Science and Experience, 2016, vol. 9, iss. 10, pp. 2-14.

URL: https://cyberleninka.ru/article/v/realnye-optsiony-kak-instrumenty-upravleniya-proektnymi-riskami (In Russ.)

10. Huss W.R. A Move Toward Scenario Analysis. International Journal of Forecasting, 1988, vol. 4, iss. 3, pp. 377-388. URL: https://doi.org/10.1016/0169-2070(88)90105-7

11. Hargitay S.E., Shi-Ming Yu.S. Property Investment Decisions. A Quantitative Approach. Routledge, 1993,352 p.

12. Bradfield R., Wright G., Burt G. et al. The Origins and Evolution of Scenario Techniques in Long Range Business Planning. Futures, 2005, vol. 37, iss. 8, pp. 795-812. URL: https://doi.org/10.1016/j.futures.2005.01.003

13. Mietzner D., Reger G. Advantages and Disadvantages of Scenario Approaches for Strategic Foresight. International Journal of Technology Intelligence and Planning, 2005, vol. 1, no. 2, pp. 220-239. URL: https://ssrn.com/abstract=1736110

14. Lindgren M., Bandhold H. Stsenarnoe planirovanie: svyaz' mezhdu budushchim i strategiei [Scenario Planning: The Link between Future and Strategy]. Moscow, Olimp-Biznes Publ., 2009, 256 p. 
15. Coates J.F. Scenario Planning. Technological Forecasting and Social Change, 2016, vol. 113, part A, pp. 99-102. URL: https://doi.org/10.1016/j.techfore.2016.10.043

16. Ponomareva K., Roman D., Date P. An Algorithm for Moment-Matching Scenario Generation with Application to Financial Portfolio Optimization. European Journal of Operational Research, 2015, vol. 240, no. 3, pp. 678-687. URL: https://doi.org/10.1016/j.ejor.2014.07.049

17. Davari-Ardakani H., Aminnayeri M., Seifi A. Multistage Portfolio Optimization with Stocks and Options. International Transactions in Operational Research, 2016, vol. 23, iss. 3, pp. 593-622. URL: https://doi.org/10.1111/itor.12174

18. Topaloglou N., Vladimirou H., Zenios S.A. Optimizing International Portfolios with Options and Forwards. Journal of Banking \& Finance, 2012, vol. 35, pp. 3188-3201. URL: https://doi.org/10.1016/j.jbankfin.2011.05.003

19. Abramov A.M. [Dynamic optimization of an options portfolio based on a polynomial tree of scenarios]. Problemy analiza riska = Issues of Risk Analysis, 2012, vol. 9, no. 1, pp. 8-23. (In Russ.)

20. Bachelier L. Théorie de la speculation. Annales Scientifiques de l'École Normale Supérieure, 1900, vol. 17, pp. 21-86.

21. Eatwell J., Milgate M., Newman P. Ekonomicheskaya teoriya [The World of Economics]. Moscow, INFRA-M Publ., 2004, 931 p.

22. Wiener N. Differential Space. Journal of Mathematics and Physics, 1923, no. 58, pp. 131-174.

23. Hull J.K. Optsiony, f'yuchersy i drugie proizvodnye finansovye instrumenty [Options, Futures, and Other Derivatives]. Moscow, Vil'yams Publ., 2018, 1072 p.

24. Izrailevich S.V., Tsudikman V.Ya. Optsiony: razrabotka, optimizatsiya i testirovanie torgovykh strategii [Options: Development, optimization and testing of trading strategies]. Moscow, Al'pina Pablisher Publ., 2017, 339 p.

\section{Conflict-of-interest notification}

We, the authors of this article, bindingly and explicitly declare of the partial and total lack of actual or potential conflict of interest with any other third party whatsoever, which may arise as a result of the publication of this article. This statement relates to the study, data collection and interpretation, writing and preparation of the article, and the decision to submit the manuscript for publication. 